\title{
No More SMS from Jesus: Ubicomp, Religion and Techno-spiritual Practices
}

\author{
Genevieve Bell \\ Intel, $2111 \mathrm{NE} 25^{\text {th }}$ Avenue, Hillsboro, OR, 97124 \\ genevieve.bellaintel.com
}

\begin{abstract}
Over the last decade, new information and communication technologies have lived a secret life. For individuals and institutions around the world, this constellation of mobile phones, personal computers, the internet, software, games, and other computing objects have supported a complex set of religious and spiritual needs. In this paper, I offer a survey of emerging and emergent techno-spiritual practices, and the anxieties surrounding their uptake. I am interested in particular in the ways in which religious uses of technology represent not only a critique of dominant visions of technology's futures, but also suggest a very different path(s) for ubiquitous computing's technology envisioning and development.
\end{abstract}

\section{Introduction}

In mid-January 2004, the Reuters news service flashed out the headline "No More Text Messages from Jesus" signaling the demise of a distinctive Finnish mobile service. According to the wire story, earlier that month, Ville Nurmi, the Ombudsman for Finland's mobile services and regulatory watchdog organization, shut down a mobile service provider that offered text messages from Jesus Christ. The company, which was not named in the proceedings, promised to answer people's prayer with a text message from Jesus [1]. This service, ruled spam through a complex set of maneuvers that included a determination that Jesus did not own a mobile phone, is but one manifestation of the increasing visible intersections of spiritual practice and technological development world wide. The Church of Jesus Christ of the Latter-day Saints runs the world's largest online genealogical service; religiously inspired web logs, portals, bulletin boards, dating sites and chat rooms are flourishing the world over; the Vatican has its own text message service and pod casts, and Pope Benedict XVI his own iPod. Christian gaming software is attracting a strong following, Hindi gods have their own websites, and there is an ongoing debate about the use of Cairo's nascent wireless cloud to broadcast a single call to prayer from the city's many minaret towers. And all around the world, technology manufacturers are increasingly catering to the ways in which computational devices might support religious practices, producing religion-specific technologies and experiences.

Given the ways in which religious practices are intimately woven into the fabric of daily life in most parts of the world, it is hardly far fetched to imagine that new information and communication technologies (ICTs) might support a range of existing religious and spiritual activities, as well as helping to create new ones. Here I 
am casting ICTs broadly to include personal computers, public computing sites (i.e.: cyber cafes, web-kiosks and gaming arcades), the Internet, software, games, accessories and gadgets (i.e.: USB flash keys, etc), mobile phones, other wireless devices and the various infrastructures that support them. And indeed recent surveys of internet habits, corporate marketing strategies, and new product developments, all point to the fact that there is a growing (perhaps already grown) segment of the population that uses technology to support religious practices, what I am calling "techno-spiritual practices". Some of these techno-spiritual re-purposings have been documented [2-8], some have been theorized [9-15], and some have been playfully and thoughtfully explored and elaborated [16-18], and there is certainly a growing literature about the impact of new technologies on Islamic practice [19-23], and wellrehearsed arguments on technological avoidances and resistances in certain religious communities [24-25]. For the most part, however, religious or spiritual relationships to, and usages of, ICTs seem to be marginalized to the realm of technological oddities, fodder for cheeky web logs and the occasional appearance in the pages of the New York Times or Wired, written off as just another trend.

However, it is my contention that these examples of the ways in which new technologies are delivering religious experiences represent the leading edge of a much larger re-purposing of the internet in particular, and of computational technologies more broadly, that has been underway for some time. Furthermore, as I have argued elsewhere [26] that ubicomp's frame of reference should extend to include any ICT that has a ubiquitous presence, this re-purposing could also be a subject of regular discussion or activities, developments and deployments in the ubiquitous computing (ubicomp) community. These techno-spiritual re-purposings are important for the ways in which they highlight alternate paradigms for technology creation, deployment, consumption and resistance, as well as pointing to different communities, practices and habits that could be supported. Furthermore, these repurposings seems to be of critical importance as the realm of technological infrastructure extends progressively beyond the office, into the home, and many other points of social and cultural significance, including one presumes, places of worship, ritual and meditation. After all, life also happens in the sacred domain.

Between 2001 and 2004, I conducted a multi-sited ethnographic research project that sought critically interrogate the ways in which cultural practices were shaping people's relationships to new ICTs in urban Asia [27-28]. Informed by contemporary anthropological theory, the research followed a range of ICTs through seven different sites of production, consumption and resistance, encompassing urban life in India, China, Malaysia, Singapore, Korea, Indonesia and Australia. I relied on a range of ethnographic methods and methodologies, including participant observation, semistructured interviews, 'deep hanging-out', and genealogies of ICTs to explore life in one hundred very different Asian households. Throughout the fieldwork process, and on many occasions since then, I have been stuck by the ways in which people's narratives of technology (and life) carried strong references to religious practices, spiritual life and ritual. However, whilst this paper is informed by that research, it does not represent a report on a bounded project that set out to investigate technology and religion at a set of specific sites; rather it is theoretical intervention into the ways in which we constitute ubiquitous computing and what we imagine to be its primary foci. As such, this paper is classic ethnographic intervention - it is descriptive and 
interpretative but not simply reportage, it is grounded in anthropological theory and praxis, and ultimately it is less concerned with "implications for design"' and more concerned with implications for theory [29]. Drawing on my fieldwork in Asia, as well as an ethnographically informed survey of religious expression and practice on new technologies (including the internet, mobile phones and computers), I articulate a relationship between religion and technology and explores the impact of such a relationship on ubiquitous computing.

In this paper, I argue that we need to design a ubiquitous computing not just for a secular life, but also for spiritual life, and we need to design it now! In no small part, this sense of urgency is informed by an awareness of the ways in which technospiritual practices are already unfolding; it is also informed by a clear sense that the ubicomp infrastructures we are building might actively preclude important spiritual practices and religious beliefs. A survey of these new technologies of enlightenment - that is ICTs being repurposed support a range of non-secular activities - reveals unexpected richness and complexity. Here I am interested in both excavating the ways in technology and religious practices have always been interpolated and also theorizing the impact of such an interpolation on ubiquitous computing; in particular the ways in which religious uses of technology represent not only a critique of dominant visions of technology's futures, but also suggest a very different path(s) for ubiquitous computing's technology envisioning and development. This paper is divided into three sections: (a) a theoretical framework within which to explore techno-spiritual practices; (b) a survey of the range of techno-spiritual practices with a focus on the mobile and internet spaces; and (c) finally a discussion of the impact of techno-spiritual on our imaginings and theorizing of ubiquitous computing.

\section{A Theoretical Framework for Techno-spiritual Practices}

Tirumal lives with his mother in the house in which he grew up in central India. ${ }^{1}$ Every morning, before the rest of the household awakes, his mother paints muggu designs - white chalk outlines - on the concrete pavement outside of their gates to bring the house good fortune and prosperity as well as to protect her family from illhealth and ill-will. Most Telegu houses have such symbols painted at their doorways, as do many other Indian homes. To an untrained eye, these symbols appear to be little more than decoration. However, at a metaphoric level, this design and the practices it indexes suggest a very different conception of relationships between public and private spaces than found in many western homes. Furthermore, it alludes to a complex framing of danger and security that could imply new home networking, virus alerts and infrastructure securities solutions. What if protection is not about repelling attack, but courting good fortune? Might this inspire different design choices, different rhetorics, and even different technologies?

For Tirumal and his family, religion, and spiritual practices are seamless woven into day-to-day living. For others, it is about praying every day, or visiting the temple, or the mosque, or church, or consulting the ngongli [lunar almanac], or counting the

${ }^{1}$ In keeping with anthropological ethics, the names of people interviewed in the field have been changed throughout this paper protect confidentiality. 
rosary. It might be individual activities, or those which connect an individual to a broader community of practice or perhaps a larger community undertaking. All of these practices are part of the fabric of daily life. In fact, in many cultures it is impossible to delineate between religious practices and beliefs and the larger structuring of society. In countless and not always subtle, ways religion shapes ideas about time, space and social relationships. Think, for instance, about the ways in which religion impacts the calendars; our distinctions between work days and rest days, holidays (i.e.: Christmas, Passover, Diwali), the reckoning of new years, even when the calendar commences are all products of various forms of religious thought. And this is as true for the major prophetic religions (i.e. Christianity, Buddhism, Hinduism, Islam and Judaism), as it is for more 'pre-axial' religions, including most First Nation religions. And while some nations might define themselves as secular, or endorse no state religion (the United States for instance), given than more than threequarters of the world identifies itself as religious, religious identification seems a significant part of what it means to be human. There is some debate about the exact figures here, but there are approximately 2 billion Christians, 1.3 billion Muslims, 900 million Hindus, 360 million Buddhists and 225 million people practicing Chinese traditional religions. In addition there are an estimated 95 million practitioners of African religions; more than 150 million people glossed as 'indigenous' religions, 23 million Sikhs, 14 million Jews, and at least 1 million neo-pagans (including 70,000 individuals in New Zealand who declare themselves followers of the Jedi Faith). And of course there are many people who identify with two religious faiths predominantly indigenous peoples. There are also estimate to approximately $15 \%$ of the world's population that is 'non-religious', secular, agnostic and atheist this includes many whose governments declare their populations 'agnostic.' There are few other practices or shaping narratives that impact so much of humanity.

\subsection{Religion in Ubicomp and Beyond}

Despite the almost fundamental nature of religion, the notion that computational technology might support religious or spiritual practice appears elusive in the broader HCI community. In 2000, in one of the first and only attempts I can find to include the spiritual in conversations about technology development, more than 50 people attended a special interest group session at the annual Computer Human Interaction Conference. The session framed around the question "Can We Have Spiritual Experiences online?" was apparently a lively one. In the paper that followed that session, participants wrote: "the dominant design rhetorics of design work in humancomputer interactions (command-and-control; constant updates and interruptions of new information; fast-action games; denotative, explicit clarity rather than connotative, exploratory ambiguity) worked against what we called the "inner stillness" of spiritual life" [11: 82]. This opposition of HCI and a spiritual life reinforces the idea that technology and religion must exist in constant tension; each precluding a complete fulfillment of the other. In 2005, Joseph Jofish Kaye and I organized a workshop at the first Ethnographic Praxis in Industry conference, in which we sought to foreground and explore this tension [30].

It strikes me that this ideological and rhetorical separation of religion and technology informs an implicit understanding of the kinds of cultural work that 
technology should, does, and could perform. To date, these assumptions actively shape the narratives of ubicomp's future - in both the visionary talk of various technology gurus and in the specifics of technology design, manufacture, and deployment. Computational technology, within the ubicomp framework, supports work practices, mobility, urban sociality, leisure activities, health concerns and certain forms of social and institutional relationships - remote communication and monitoring in particular. There have also been attempts to expand the conversation to include notions of pleasure, affect, and intimacy [31-33]. But an ubicomp technology or design deployment for spiritual practice remains notably absent.

So how might we talk about the nascent techno-spiritual usages of ICTs? How might we celebrate these practices in our tales of cyberspace and technological utopias? To talk about religion is to traverse contested ground that is highly personal and emotional and increasingly politicized. In much of the western scientific tradition in which many of us were trained, religion is held as an opposition; in this framework, technology and computing embody rational thinking and logic, not religion, the spiritual, perhaps the mystical. This positioning is of course, deeply ironic, and oddly a-historical. After all, in the West, there is a long and complex relationship between technology and religion; religious institutions have been quick to adopt the advances that allowed them to operate with greater efficiencies and/or efficacies [34]. In his provocative book, The Religion of Technology [35], Noble advances this argument about the relationship between technology and religion one step further, claiming that technologies rapidly scaled only at the point that they were invested with spiritual significance.

\subsection{An Approach Informed by Anthropology}

So how might one approach the techno-spiritual? In this paper, I propose to rely on anthropological framings of both religion and technology as a way of unpacking the seeming contradictory nature of techno-spiritual practices. Throughout this paper, I am interested not only in the anthropology of religion per se, but in also in a wider set of disciplinary practices that include a grounded epistemological discourse, notions of cultural production, a focused attention on the particulars of place and location and critical reflexivity [29, 36-38].

Anthropologists have been interested in making sense of the function of religion within a society, as well as the details of particular religious practices. For anthropologists of religion, many activities can be of interest: specific activities carried out within and framed by a larger belief system (i.e.: rituals and practices [39]), the framing systems themselves (i.e.: theology, dogma, mythology [40-44]), the ways in which such framing systems are resisted or transformed (i.e.: syncretism [4548). From the early work on "primitive religion" and comparative explorations of ritual and magic [49, 39], studies of religion within anthropology remain influenced by Durkheim, Weber, Marx and Freud, among others [50-52]. Weber's insistence on the common links between social and economic spheres of action seems to be a particular useful thread here in positing common links between religious and technical spheres of action.

In one of the definitive articles on the subject, Geertz defines religion as "a system of symbols which acts to establish powerful, pervasive and long-lasting moods and 
motivations in men [sic] by formulating conceptions of a general order of existence and clothing these conceptions with such an aura of factuality that the moods and motivations seem uniquely realistic" [39:90]. In other words, religions are a form of cultural logic or patterning that makes unique and distinct sense within a particular cultural context; religions are also an expression of those cultural contexts. It is this dialectic that is particularly important when thinking about the interplay of new technologies and religious practice. In this paper, I am interested in the larger formulations of religious practice as manifested by institutions (i.e.: formal religious structures and organizations) and also by individual practices - both religious and spiritual activities.

Today, in anthropology, we understand religion to be a sort of cultural script - a strong framing narrative for daily life in many parts of the world. Similarly, the very idea of technology has also always already been subject to ethnographic interpretation and scrutiny [53-54]. As such, it is easier to imagine the relationships between technology (and the theology of progress it encodes) and religions; after all within the ethnographic tradition both are sites for the production of cultural meaning, both are narratives. In as much as I am interested in thinking about religion as a cultural system or site of cultural production, I am also interested in scrutinizing technology through the same filters. It is certainly the case that new technologies do technical work, but they also do cultural work, and it is this latter work that is of particular interest in this paper.

This interpretation of technology owes much to the contemporary literature on consumption, consumer and material culture, in particular the work of Appadurai [5556] and Miller [57] whose framing of objects and contexts of use help recontextualize and locate technologies within particular cultural moments and practices. This attention to the cultural life of technology might help, in part, to explain why the tension between religion and technology is not felt so acutely in other parts of the world. In the western tradition, especially in this late capitalist, postEnlightenment era, ICTs are linked to the cultural narratives of progress, change and even revolution. Without engaging in a kind of techno-orientalism, I think it is possible to argue that ICTs (and technology more broadly) map to alternate cultural discourses within Islam, Hinduism and Confucianism, just to name a few. This alternate mapping could produce different kinds of anxieties, adoption patterns and even framings of computational offerings. As such, throughout this paper, I will be cataloging techno-spiritual practices from a range of different religious and cultural traditions.

In addition to an anthropological framing of religion and technology, my treatment to techno-spiritual practices is shaped by the work of George Marcus, and his theorizing of multi-sited ethnography. Clearly, I am stitching together acts of many individuals and organizations in disparate locations and cultural contexts, sometimes sharing a common religious context. All the while, I am, to play on Marcus's words "tracing the circulation through different contexts of a manifestly material object of study (at least as initially conceived)" [58:91].

Elsewhere I have written about 'defamiliarization' - the act of making the familiar strange - as a methodology intervention that allows one to explore hither-to-fore implicit assumptions about domestic design [59]. In this paper, I propose to revisit the notion of defamiliarization as a way of unpacking and exposing our own assumptions 
about the kinds of work that technology could or should do. Here I am mindful of Marx's charge that religion sometimes functions as an opiate for the masses, and I am acutely aware of current geo-political sensitivities to issues of religion. One of the hallmarks of ethnographic epistemology is rigorous attention to and practice of critical reflexivity. By this I mean, that within ethnographic modes of inquiry and production, the subjectivity of the researcher is an important component - knowing who I am helps the reader situate my analysis and critique. As Ruth Frankenberg [60] has recently argued, in turning the ethnographic lens on contemporary religious practice, a nod towards reflexivity becomes more than just perfunctory. I am a cultural anthropologist with a primary concern in information technology as a site of cultural production and the consequences for technology innovation and diffusion. I am also the child of a symbolic anthropologist, and I grew up straddling multiple domains of religious signification in Australia - Catholicism and Catholic schooling; indigenous religious practices; a strongly agnostic home life; and close familial relationships with cultural and practicing Judaism. I am, as an Indian woman with whom I once worked described me, "a free thinker". As such, I find myself more interested in the study of religious practice than I am in endorsing a particular vein of religious dogma.

\section{A Survey of Techno-spiritual Practices}

In 2003, the Australia Bible Society began to offer the bible rendered in SMS or cell phone text message format on a single take-home CD-ROM. More than just a coding into short burst of text, the bible was also translated into the vernacular of SMS and of a certain imaging of youth discourses: the cover of the CD case proclaims - for God so luvd da world. The CD is designed to be loaded on a computer and Bluetoothed to a compatible cell phone and then broadcast out. This remarkable artifact, now augmented with a full website, was marketed as a tool to help pastors, youth group leaders, and other technology savvy Christians share the Bible with a wider range of their friends, acquaintances and parishioners.

This blending of ICTs and spiritual practices might seem surprising in a nation that casts itself as a secular one, without a state religion. However, such techno-spiritual practices seem to abound in both secular and religiously identified nations. Clearly, in some countries, governments do not have a role in the religious landscape; in others, endorsement or sometimes regulation of religious practice is not uncommon. Irrespective of government structure, scratch the surface of almost any nation, you will find an unexpectedly rich landscape of techno-spiritual practices. These practices operate through and with a range of ICTs and it is by making strange, or defamiliarizing, some of the most common of those - the cell phone and the internet that such practices are revealed.

In American almost $70 \%$ of the population makes use of the internet regularly. The contours of American usage of the internet appear well documented: web-surfing, communication, data gathering, personal finances, e-commerce, gaming, pornography, gambling. Yet, according to a recent report by the Pew Internet and American Life Project, 64\% of online Americans have also used the internet for religious or spiritual purposes [6] - this includes sending and receiving email and 
digital greeting cards with spiritual content, reading news accounts of religious events and affairs, and seeking information about religious holidays, services and events. These 128 million Americans utilizing the web for religious practices outnumber Americans gambling, using web auction sites, trading stock or doing online banking [6]. And whilst the slim majority of these users were female and little older, research at the University of North Carolina suggests that three times more teenagers access the web for religious purposes than for pornography [61]. This might suggest that younger Americans, often heralded as the internet generation take the religious aspects of the web as a given. American churches too have embraced ICTs deploying wireless networks, utilizing PowerPoint, websites and DVDs, as well as videoconferencing and email to connect with their parishioners - several interesting studies are underway to explore the impact of such deployments on church and spiritual life [62-64], and others are testing the relationship between religiosity and internet use in America [65]. And one can well imagine a series of projects exploring aspects of spiritual and religious practice as they related to ideas of community - and there is certainly much to suggest that ICTs can play a role in community building, as well as emotional and motivational support $[11,54,66-68]$. So if this is what is happening in the United States, an apparently well documented population when it comes to technology consumption, what might be happening elsewhere, slightly out of line of site? In the rest of this section, I provide a survey of techno-spiritual practices in both the mobile and internet spaces - in so doing, I hope to defamiliarize these seemingly familiar technologies and suggest alternate paradigms and patterns of use.

\subsection{Mobile Techno-spiritual Practices}

In Guangzhou, Gloria, a young woman in her late twenties, takes her mobile phone to a local Buddhist temple in the days before Chinese New Year. For a small 'ang pow' (red package) of money, a monk will bless it. When I ask what kinds of monks bless mobile phones, she tells me "well, old monks are best, but young monks are cheaper." Gloria also buys a jade amulet from the stalls outside the temple gates, and hangs it from her phone. For her, these acts and actions make the phone wearable; it can now rest around her neck, close to her body, closer to heart, without fear that it is causing her harm. Through this ritual of blessing, the phone is naturalized and incorporated safely into Gloria's daily life. Gloria is not alone in her ritual practices: many other young people through out China engage in similar activities in anticipation of the Chinese New Year.

The mobile telephony and communication space is clearly rich with spiritual possibilities, moral uplift and tools for devotion. Indeed, the intimate nature of mobile phones has lent themselves to all manner of inclusion within religious systems of practice [7]. Some practices extend an individual's spiritual capacity, allowing participation in events that would otherwise be geographic impossible. For instance, it is now possible to place a prayer at the Wailing Wall in Jerusalem via text-messages through a Russian mobile service provider. The text of the prayer is printed out and deposited at the Wall; the text also appears on a public display screen near the Wall [69]. This kind of remote participation extends into other domains of religious and spiritual activity too. Until March of 2003, in the Philippines, it was possible to send your confession and receive absolution via text message on a mobile phone; you 
could also confess via email or fax. This practice, which was obviously growing, came to light when a local Monsignor ruled that electronically mediated confessions were no longer acceptable, nor was granting absolution via the same mechanisms. Monsignor Cornel said "We have to protect that confidentiality and we insist on personal confession of the penitent to the priests" [70]. The security of the channel and the fidelity of the message seemed in question; according to one report, the Bishops were concerned about the confidentiality of confession and the sacrament. Whilst confession via SMS might represent a kind of rational efficiency, it thwarts much of the religious intent of confession as a semi-public act of contrition and subsequent state of grace which many would argue can only transpire inside a church. One suspects that providing greater levels of security provisions for electronically mediated communication is not the answer here.

Of course there are other instances of new technologies extending the reach of religious institutions without disrupting their core beliefs and practices. In Rome, the Vatican itself is embracing the potential of ICTs to reach a larger audience. Commencing in January of 2003, the Vatican in conjunction with Telecom Italia, Italy's largest mobile phone service provider, launched a daily text message service [71]. For US $\$ 0.15$ per day, subscribers to the 'papa on' service were treated to thoughts and prayers from the Pope, including "as long as there is the spring of the spirit, good blooms" and "one should never stop praying for peace." There were more than 2 million subscribers to the service by the end of March 2003. In a time when church attendance was falling off in Italy; this represented an opportunity for unparalleled access. In May of 2004, three of the four major mobile services providers in the United States were quietly carrying this same service [72] - the implications here is even more interesting, given the doctrinal and ideological fissures between Rome and American Catholics. An in-depth analysis of the text of this service would be a fascinating study.

Mobile devices can also facilitate many daily religious rituals and practices. For devout Muslims, there is an expectation that one must pray at five particular times of the day, in a mosque if possible, but always facing Ka'bah in the city of Mecca. This direction is called qiblah or qiblat. In Malaysia, a self-styled 'modern' Muslim country, the latest generation of mobile phones allows users (through a simple software application) to find Mecca, via a 'm-qiblat' service. You can also download the Koran to your palm-pilot, and synchronize it to local prayer times for 1100 cities around the world. In 2003, Ilkone Mobile Telecommunications launched a new 3G cellular handset for the Middle East with the tagline: your phone, your life. This new handset explicitly caters to Islamic users. It has GPS-like functions which enable the handset to point its user to Mecca from any point on the globe and determine the appropriate local times to pray, polyphonic sound, Bluetooth capacities and the use of wireless networks can bring any user the call to prayer in the live voice; it calculates fasting times for Ramadan and has the entire of the Koran in Arabic and English stored on the handset. It also offers a mosque-function which disables the phone for a short period of time at salat so as not to inadvertently ring during prayer. This function can be read as a direct challenge to the notion of constant connectivity that periodically pervades ubicomp discourse. Here a technology is designed to be disconnected, rather than always-on. In thinking about designing for techno-spiritual practices, we might have to consider a different range of practices and priorities, and 
conceptualization of space and location that is driven by a broader set of use patterns. The Ilkone phone is a powerful reminder of the importance meditation, prayer or quiet time in sacred spaces is accorded in most religious systems.

There are now also various independent service and content providers the globe over offering forms of spiritual messaging on the mobile phone platform; Lent text messaging packages with Gospel verses every day at midday, religious ring-tones and hymns, the Rosary and Stations of the Cross in java applications, even Feng-Shui on your phone. Until February 2005, China Mobile and other mobile service providers have offered their customers the lunar almanac via text message. However, in a surprise move, coming immediately only a week before the Year of the Rooster began, the State Administration of Radio, Film and Television banned "any advertisements that harm young minds or violate regulations" through the promotion of superstition - this included 'birthday decoding', and 'new year fortune telling' text messages and phone services. Shares in China Mobile and Sina took an immediate beating on the market as it became clear that much of their revenue stream was derived from these very popular and culturally grounded services.

Elsewhere, in the Catholic world, there are concerns about the possibly negative impact of text messaging and mobile phones. During Lent, in 2002, the Archbishop of Salerno had proposed that Good Friday should be text-message free; "I'm asking this little sacrifice to my faithfuls to make clear the church's position," he said. "In a world dominated by the culture of possession, we should try to focus more on meditation, and leaving behind our mobile phones for a day will surely help" [73]. Other Catholic Churches in Europe, South America and Asia have commenced the installation of cell-site dampeners to preclude cell phone use during services. In one Seoul church I visited the sign in the vestibule read "turn off your cell phone and listen for the call of God." In several Muslim nations, debates are ongoing about the role of textmessaging in divorce proceedings and in India; several organizations are claiming a connection between the rise of text-messaging and a rise in divorce rates.

There are also ways in which new technologies are being naturalized, or incorporated into culture through religious systems at a symbolic level. In traditional Chinese culture, as part of funerary arrangements, people burn paper goods at the death of relatives. The fire transforms the paper into real artifacts in the world that the ancestors now inhabit. In addition to the funeral pyres, paper objects are also burnt at QingMing. Every year, Chinese people around the world visit the tombs of their ancestors to sweep the graves clean - this ritual time known as QingMing (or ChingMing) has been part of the Chinese calendar since the 700s. Traditionally, people burnt paper currency and also paper representations of common household good - clothes, furniture, food, and other luxury goods. Throughout the Chinese disaspora, a range of technologies have been added to the paper array burnt at funerals and QingMing, including televisions, fans, air-conditioners, mobile phones and computers including both laptops and PCs. In at least two Malaysian cities in which I conducted fieldwork, QingMing had been not only an occasion for tending ancestral tombs, but also for upgrading the mobile phones of the ancestors, as well as providing them with additional pre-paid phone cards. This tending of the ancestors' telecommunication needs was all done through the burning of paper representations. This techno-spiritual practice reflects not only the centrality of mobile phones in 
Malaysian culture, but also the ways in which they have been seamlessly embedded in the daily life of the living and clearly that of the dead.

\subsection{Techno-spiritual Practices Online}

At 10AM on February 8, 1996, three Tibetan Buddhist monks in a monastery in Ithaca, New York blessed the internet. With a laptop loaded with an image of the Kalachakra Mandala, they prayed for half an hour, formal blessing of cyberspace: "We pray to reduce the negative things that may happen in cyberspace and to increase the positive things.... When we bless something, we are seeking to change its disposition - to eliminate negative things that come from that particular object - and we generate the motivation that the use of that object will be very positive and beneficial ...The person using the Internet has the choice. Whether the Internet becomes material for happiness or for suffering depends on your mind" [quoted in 13: 280]. This naturalization of cyber-space through prayer is but one indicator of the rich vein of techno-spiritual practices in and around the internet. These practices point to a wider ecology: religious expressions and rituals have found homes online in chat rooms, bulletin boards and religious portals, as well as in a range of services, content and applications and software. Sacred spaces have found web front-ends and religious communities have the potential to create new sacred spaces.

Some internet techno-spiritual practices are connected to larger religious agendas and organizations, and much like the mobile services described above, are intended to help extend the reach of a particular religious institution. For example, over the past three years, the Catholic Church has been conducting a search for a patron saint for the Internet; St. Isidore of Seville seems to be the most likely contender. In February of 2004, the Church of England launched a 'virtual parish' or i-church, "for people who travel a great deal or are unable to attend regularly, i-church can support them spiritually wherever they are in the world." The Church also announced it an opened a search for a pastor to oversee this new parish.

There are also other Christian websites, not linked to any specific churches or particular religious communities that are designed to support one's spiritual and moral development. There are discussion groups and chat rooms dedicated to religious topics, faith FAQs, and uplifting daily messages [74]. One such site provides a survey that helps users determine their best religious fit, another offers a count-down to Armageddon and the rapture. There are also websites with a moral edge: movies reviewed for their Christian content, online sport support sites with uplifting testimonials and a proliferation of "Christian-friendly" dating and social networking sites [75]. There are also a range of dating sites for other religious dominations and faiths, and arranged marriages organized over the web remain popular in India. In many ways, these religious sites are not that different from other interest-specific websites and services.

The technologizing of sacred spaces does offer a slightly different take on technospiritual practices. Whilst the monks who support the website 'nextscribe.org' believe that the internet as a network can be read as a sort of church, there are more instrumentalist uses of the internet already at work. Various sacred places and shrines in Asia (and the West) have their own websites, and new forms of virtual pilgrimages, digital relics and techno-spiritual practices are emerging [66]. For instance, a temple 
dedicated to the Hindu deity, Ganesh has its own website from which you can procure religious artifacts and makes acts of devotion. In neighboring Sri Lanka, one of the first local websites to go live offered virtual parrot auspice to Sri-Lankans all over the world. You can even add your own request for prayers at the website for the chapel of the Franciscan Sisters of Perpetual Adoration in Wisconsin, where the sisters have been praying continuously for 125 years. Avi Moskowitz has created a "Virtual Jerusalem" on line, among many other features; the site allows registered users to send prayer to the Wailing Wall.

In addition to all these online extensions of real places, are also a set of sites supporting familiar rituals in new ways. The Chinese government is actively supporting the creation of online memorial halls to facilitate the time honored filial practice of ancestor worship. In China, QingMing changed after the Revolution. While there is some burning of paper currency, there has been less elaboration of paper goods and rituals, especially during the early years of the Revolution. In recent years, the Chinese government has been attempting to "modernize" Chinese funerary practices. "The authorities argued that traditional forms of tribute waste money, cause fires and encourage superstition. According to ministry figures, Chinese people spent 16.2B Yuan (US\$2B) a year on funerals and paying respect to the ancestors" [76].

In 2001, the Chinese government launched "Earth Village" - an online cemetery and issued a notice to all local governments requiring that they promote the site [Bezlova 2002]. Earth Village is one of a growing number of Chinese-based online memorial halls; according to one source there are more than 100 such sites in operation [77]. At EarthVillage, you can choose from one of 12 e-tombstones, burn eincense and leave e-flowers. "Netor", another funeral site, has more than 11,000 memorials to the dead at its portal; the company charges between 100-1000 Yuan (US\$12-120) for a thirty day memorial site, ranging from a simple photo to streaming video [78]. In 2001, they estimated that they were receiving more than 600,000 hits per day [79]. "Wangtong", another of the funerary portals that operates locally in Shanghai, estimated that it has 20,000 such halls and as a result receives more than 10,000 daily visits and plans to start offering SMS memorial services [77]. There are several other QingMing portals that serve Chinese communities beyond China and their popularity continues to grow [80]: there were some reports of an upsurge in Singaporeans use of cyber QingMing services during April 2003 as a way of sidestepping SARs concerns and quarantines on the island-state.

New ICTs are also finding their way into the physical places in which people worship, meditate and pray. For example, worshippers in a Lutheran church in the small Swedish village of Norrfjaerden who can use their credit and debit cards to tithe [81]. Perhaps of greater interest, however, are also the ways in which new computational objects are making any space a sacred space. The availability of religious tracts and texts on various forms of media - god-casting [82], the BiblePlayer for iPod or on secure digital and other flash memory for PDAs transforms ICTs into tools for religious and spiritual devotion. Building, one suspects, on the enduring popularity of Christian music (and other Christian themed content), there is a growing market of Christian gaming software [83-84], from Charlie Church Mouse Bible Adventures [83] to Catechumen in which a player goes through catacombs of Rome to free their mentor and fellow Christians, and convert demon possessed Roman soldiers. The 'ghost radar' - a ghost detector USB flash stick from 
SolidAlliance which promises to illuminate the presence of ghosts; electronically augmented grave-stones, live-web cams at funerals and the practices of carrying death photos on cell-phones all point to another domain of the techno-spiritual.

Of course not all emergent practices are in support of established religious communities or practices. Members of Falun Gong, a religious community banned in China in the late 1990s, are hijacking new technologies to broadcast religious content, assertions of innocence and claims of harassment to Chinese citizens. As the official Chinese newspaper put it, "Although the cult has been banned in China, its leaders in foreign countries still the use the internet and other high technologies to control the followers to carry out destructive acts in China ...". Throughout 2002, Falun Gong hacked various Chinese television infrastructures, including local cable television and even SinoSat (one of Chinese national communication satellites), to send out messages about the group to the general public. Similarly, the group has found ways to take advantage of Chinese language chat rooms to spread their message; they have leafleted entire communities with video-discs, and they have used automated phone calling systems to call multiple numbers and play a recorded message. Here technospiritual practices focus on disrupting pre-established practices, challenging dominant discourses around religious identity.

\section{Towards Spiritual Design?}

In Mark Weiser's now famous future vision of ubiquitous computing, he wrote "we are trying to conceive a new way of thinking about computers in the world, one that takes into account the natural human environment and allows computers themselves to vanish into the background" [85: 94]. As one reflects on the range of spiritual and religious practices occasioned through and with new ICTs, one is stuck by the ways in which the religious and the spiritual are fore grounded. All kinds of different peoples and communities have already asserted the importance of their own cultural practices and co-opted ICTs accordingly. But what might it look like if we explicitly imagined religion and spirituality as part of Weiser's "natural human environment"? In his wonderfully textured story of Sal and her daily life, however, these are missing. Sal's life moves between two dominant sites of cultural production - the home and the office; it moves between two modes - leisure and work. Nowhere is there a sense of Sal's inner spiritual life - indeed, one might think she did not have one. As part of a corporate exercise to develop a future vision for user-centered computing in 2015, I wrote the two scenarios below [86]. I am choosing here to eschew the traditional section on 'implications for design' [29] and instead invite the reader to engage with me as a co-interlocutor, as we imagine a near-future in which computational technologies might actively and explicitly support techno-spiritual practices.

Li lives and works in upstate New York with her husband. She has family in Beijing and Hong Kong; they keep in touch through regular calls, emails and photos. Li's grandfather died in the fall after a long and prosperous life. After his cremation, the family added a new wing to their ancestor hall online. Different family members add photos, video, even long forgotten conversations. Li sends her own contributions - the smell of her grandfather's study with its cedar boxes of ancient calligraphy that her grandfather collected and preserved. Once the addition is complete, the family's 
various ancestral tablets are updated. Li's tablet resets itself and her grandfather's name joins the list of other names that can be seen in Li's hallway. The tablet emits the smell of burning incense to alert Li to the presence of her grandfather's name. At QingMing, families gather to 'sweep' clean their family tombs and feed, clothe and care for their ancestors. For Li's family, ancestral tablets around the world sound chimes to gather family members across different time zones. Li brings oranges and paper money to her hallway, the ancestral tablets glow more brightly as more and more family members stand before them in care of their ancestors.

Daniel lives with his parents in a satellite suburb of Chicago, he is eleven years old. Daniel has always lived in America, but he has cousins in Europe and the Middle East. In fact, his parents are the only ones who live in America. Still the whole family tries to gather once a year, usually for Passover. The adults like to spend time together talking about the happenings of the previous year, the ups and downs of business, family life, politics ... but for the kids, it is a chance to get together and play. This year, Daniel's parents won't be able to travel; there are just too many uncertainties and dangers, but they will still make it to the family Seder. In Europe, the extended family is taking advantage of their newly remodeled 'smart' home to create a 'digital'/real Seder. The kitchen is recorded and broadcasting the smell of brisket being prepared - in Daniel's kitchen he can smell faint hints of this traditional meal. It is also wafting to his cousin's house in Jordan. Later in the evening, the whole family will participate in the Haggadah - with the family taking it in turns to read. And because Daniel is the youngest, he will ask the Four Questions. Voices carry across thousands of miles - the traditional arguments and jokes. And the smell of food lingers. Aunty Rebecca has projected an orange onto everyone's Seder plate, again. And Daniel's grandparents have found a way to hide the afikomen (it's in Daniel's kitchen, projected onto the fridge). Seders in Daniel's family go on for hours. And this year, he is really missing his cousins at the kid's table, but his parents have created a virtual kid's table for him, and all the cousins are gathered there too. They joke around, reciting when they are called upon, and stealing food from their parent's plates.

So how might an understanding and awareness of the importance of religion impact the ways in which ubiquitous computing is developed and deployed? Clearly, as we move to the possibility of computing beyond the desktop and home office, to wireless hubs and hotspots, and from fixed devices to an array of mobile form factors, the need to account for the diversities of daily life starts to impose itself into the debate. In no small part, paying attention to religion and religious practices forces us to move beyond efficiency as a useful metric for measuring technology success. Similarly, the nature of certain kinds of religious practice and expression suggest that always-on connectivity and constant updating might not be desirable features of a computing system.

Clearly there have been some attempts to grapple with the complicated issues that arise when trying to account for a spiritual domain in technology design - there have been various strategies for thinking beyond the efficiency/leisure paradigm for computing. In collaboration with PARC's anthropologists, Mark Weiser and his team were made of aware of ways in which people's daily social practices impacted their consumption and understanding of computing; "In particular, how were computers embedded within the complex social framework of daily activity, and how did they 
interplay with the rest of our densely woven physical environment (also known as the "real world")?" [87: 693]. This consideration of social frameworks and physical environments led Weiser's team to propose calm computing as a way of managing the consequences of a ubiquitous computing environment. Weiser and Brown wrote, "if computers are everywhere they better stay out of the way, and that means designing them so that the people being shared by the computers remain serene and in control. Calmness is a new challenge that UC brings to computing ... Calmness is a fundamental challenge for all technology design of the next fifty years" [88]. Gaver and others have called for an interleaving of computational and everyday worlds through the trope of ambiguity - creating possibilities for other sorts of experiences and meaning making around technologies. Researchers at Georgia Tech have been exploring computer meditated religious communications and the role of technology in spiritual formations [64], while researchers at Cornell are experimenting with shyness and other forms of non-rational interaction.

Of course, it is also important to reflect upon why we have, thus far, tended to neglect spirituality and religion when we think of non-work usages and user models around technologies. We appear to be stubbornly secular in our imaginings of home and leisure contexts for computing. What we have to do is re-image the very contexts in which those technologies are conceived, created and consumed, making room not just for fun and enjoyment but also another fundamental set of cultural and human needs. If it is indeed the case, that religion is a primary framing narrative in most cultures, and then religion must also be one of the primary forces acting on people's relationships with and around new technologies - one could go as far as to suggest that there can be no real ubiquitous computing if it does not account for religion.

In this paper, I have provided examples of the many ways in which new technologies can and do deliver religious experiences; they are the leading edge of a much larger repurposing of computing and the Internet. Religion proves a useful vantage point from which to explore how much social and cultural institutions and practices are occasioned in and through technology. The re-purposing of ICTs for religious practices challenges some basic assumptions about what makes good technology; if not about efficiency and speed, then what? How might thinking about techno-spiritual practices inform ideas of privacy, identity, and security, for instance? Religious systems' cultural logic necessarily impact the very ways in which new technologies are created, consumed, and indeed rejected. Our desire to bring new technologies into our homes; the persistence of values such as simplicity, grace, humility, modesty, and purity; and ideas about modernity, subjectivity, and the self are all implicated in shaping the contexts for new technologies. And if we ignore them, we shortchange both our own experiences of the technology itself, as well as our understandings of what it could be for others.

\section{Acknowledgements}

I am extremely grateful for the interest showed in this project at Intel. I am also grateful for the insights of Diane Bell, Nina Wakeford, Paul Dourish, Adam Yeut Chau, Debashis Chaudhuri, Eunyun Park, Jofish Kaye, Dan Russell, Peter 
Sheppard-Skaverd, Katrina Jungnickel, and Michael Erard. And I am also grateful to the anonymous reviewers who provided much useful feedback.

\section{References}

1. Anon.: No more text messages from Jesus. Reuters. 1/19 (2004), 10:50 AM EST.

2. Brasher, B.: Give me that online religion. Jossey-Bass, San Francisco (2001).

3. Beaudoin, T.: Virtual Faith: the irreverent spiritual quest of Generation X. Jossey-Bass Publishers (1998).

4. Cobb, J.: Cybergrace: the search for god in the digital world. Crown Pubs, (1998).

5. Ellwood-Clayton, B.: Texting \& God: the Lord is my Textmate, Folk, Catholocism in the cyber-Philippines. In K. Nyiri (ed) A Sense of Place. Passagen Verlag (2005).

6. Hoover, S., Clark, L., \& Rainie, L.: Faith Online. Pew Internet \& Am. Life. (2004).

7. Katz, J.: Magic in the air: Spiritual \& transcendental aspects of mobiles. Image, Understanding \& Learning in the Mobile Age conference, Budapest, (2005).

8. Larsen, E.: Wired Churches, Wired Temples. Pew Report, (2000).

9. Bell, G.: The age of auspicious computing: ethnographic accounts of religion \& new technology. ACM Interactions. Special Issue on Play. 11:5 (2004), 76-77.

10. Bell, G.: "Auspicous Computing?" IEEE Internet Comp, 8: 2, (2004).

11. Muller, M., Christiansen, E., Nardi, B. \& Dray, S.: Spiritual Life \& Information Technology. Comms of ACM, 44: 3, (2001), 82-83.

12. Swanson, D.: The Framing of Contemporary Christian Apostasy on the World Wide Web. Jrnl Media \& Religion, 3:1, (2004), 1-20.

13. Zaleski, J.: The Soul of Cyber Space: how new technology is changing our spiritual lives. Harper Edge (1997).

14. Campbell, H.: Making Space for Religion in Internet Studies: Info Soc, 21: 4 (2005).

15. Davis, E.: Techgnosis: myth, magic + mysticism in the age of information. Three Rivers Press, California (1997).

16. Aloy, L.E.: Oh Maria Keep My Data Safe. The Show, Royal College of Art, 2005.

17. Hlubinka, M., Beaudin, J., Tapia, E.M., An, J.: AltarNation: interface design for meditative communities. In CHI '02. ACM Press, New York, NY, 612-613, (2002).

18. Ozenc, S.: Sajjadah 1426. St Martins College Art \& Design, London (2005).

19. Anderson, J.: The Internet \& Islam's new Interpreters. In: D. Eickelman, J. Anderson (eds). New Media in the Muslim World. Indiana Uni. (2003).

20. Blank, J.: Mullahs on the Mainframe: Islam \& Modernity Among the Daudi Bohras. Uni of Chicago (2002).

21. Bunt, G.: Virtually Islamic: Computer-mediated communication \& cyber-Islamic Environments. Uni. of Wales Press (2000).

22. Eickelman, D. \& Anderson, J. (eds).: New Media in the Muslim World: The Emerging Public Sphere. Indiana Uni. Press (1999).

23. Lawrence, B.: Allah On-Line: The Practice of Global Islam in the Information Age. In S. Hoover, L.S. Clark (eds): Practicing Religion in the Age of the Media: Explorations in Media, Religion \& Culture. Columbia Uni. Press (2002).

24. Reingold, H.: Look Who's Talking. Wired. 7: 1 (1999), January.

25. Erard, M.: The Geek Guide to Kosher Machines. Wired,12.11(2004), November.

26. Bell, G. \& P. Dourish.: Yesterday's Tomorrows: Notes on Ubiquitous Computing's Vision. Personal \& Ubiquitous Computing. In Press. (2006) 
27. Bell, G.: The age of the thumb. In: P. Glotz, S. Bertschi \& C. Locke (eds.): Thumb culture: Social trends \& mobile phone use. Verlag, (2005): 67-88.

28. Bell, G.: Satu Keluarga, Satu Komputer: Cultural Accounts of ICTs in South \& Southeast Asia. Design Issues, Vol 22:2. MIT Press (2006).

29. Dourish, P.: Implications for Design. Proc ACM Conf Human Factors in Computing System, CHI (2006), 541-550.

30. Bell, G. \& J. Kaye.: Holy Hanging Out: Exploring Spirituality \& Religion in the Corporate Environment. Ethnographic Praxis in Industry, November (2005).

31. Bell, G.: "Intimate Computing?" IEEE Internet Comp., 8:6, (2004).

32. Bell, G., T. Brooke, E. Churchill, \& E. Paulos.: Intimate (Ubiquitous) Computing. Workshop, UBICOMP, Seattle, October (2003).

33. Brewer, J., Kaye, J., Williams, A., \& Wyche, S.: Why we should talk about sex in HCI. Workshop. CHI (2006).

34. Lynch, C.: Selling Catholicism: Bishop Sheen \& the power of television. Uni. of Kentucky Press (1998).

35. Noble, D.: The Religion of Technology. Apfred A Knopf (1997).

36. Clifford, J. \& Marcus, GE.: Writing Culture: The Poetics \& Politics of Ethnography. Berkeley: Uni of California Press (1986).

37. Holmes, D. \& Marcus, G.E.: Refunctioning Ethnography within Cultures of Expertise. In: Yvonne Lincoln \& Norm Denizen (eds.): Handbook of Qualitative Research. $3^{\text {rd }}$ ed.. Thousand Oaks: Sage Publications (2005).

38. Geertz, C.: Local Knowledge. New York: Basic Books (1983).

39. Frazer, J. G. The Golden Bough: A Study in Magic \& Religion. Macmillan, (1922).

40. Geertz, C. Religion as a cultural system. In: The Interpretation of Cultures. Basic Books (1973), 87-125.

41. Levis-Strauss, C.: The Raw and the Cooked. New York: Harper \& Row (1969).

42. Weber, M.: The Protestant Ethic \& Spirit of Capitalism. NY: Scribner's (1958).

43. Wallace, A. F.C.: Religion: An Anthropological View. NY: Random House. (1966).

44. Geertz, C.: The Religion of Java. Chicago : Uni of Chicago Press, (1976).

45. Brown, K.M.: Mama Lola. Berkeley: Uni of California Press (1991).

46. Gutierrez, R.: When Jesus Came, the Corn Mothers Went Away: Marriage, Sexuality \& Power in New Mexico, 1500-1846. Stanford Uni Press (1991).

47. Ong, A.: Spirits of Resistance \& Capitalist Discipline. SUNY Press (1987).

48. Taussig, M.: Shamanism, Colonialism, \& the Wild Man: A Study in Terror and Healing. Uni of Chicago Press (1978).

49. Evans-Pritchard, E. E.: Theories of Primitive Religion. Oxford Uni Press, (1965).

50. Weber, M.: Sociology of Religion. Boston: Beacon Press, (1964).

51. Durkheim, E.: Elementary Forms of the Religious Life. Allen \& Unwin, (1915).

52. Freud, S.: Totem and Taboo. J. Routledge \& Kegan Paul. (1913).

53. Sharp, L. Steel Axes for Stone Age Australians. In E. H. Spicer (ed.): Human Problems in Technological Change, NY, Russell Sage Foundation, (1952), 69-72.

54. Pelto, PJ.: The Snowmobile Revolution: Technology \& Social Change in the Arctic, Menlo Park, CA, (1973).

55. Appadurai, A. (ed): The Social Life of Things: Commodities in Cult. Perspective. Cambridge Uni. Press (1988).

56. Appadurai, A.: Globalization. NC: Duke Uni. Press (2001).

57. Miller, D.: Material Cultures: Why some things matter. IL: Uni of Chicago, (1998).

58. Marcus, G.: Ethnography in/of the World System: The Emergence of Multi-Sited Ethnography, Annual Review of Anthropology, 24 (1995), 95-117. 
59. Bell, G., M. Blythe \& P. Sengers.: Making by making strange: defamiliarization \& the design of domestic technologies. Trans CHI-Social Issues, 12:2 (2005): 149-173.

60. Frankenberg, R.: Living Spirit, Living Practice. Duke Uni, (2004).

61. Williamson, D.: American teens so strong interest in using Internet for religious contacts. UNC News Service. 12/10 (2003), 638.

62. Fenimore, J.: High-Tech Worship: Media Technologies \& Christian Liturgical Practice. PhD Project. RPI (2004).

63. Sturgill, A.: Scope and Purpose of Church Web Sites. Jrnl Media \& Religion, 3: 3, (2004), 165-176.

64. Wyche, S.P., Hayes, G., Harvel, L., \& Grinter, R.: Tech in Spiritual Formation: Exploratory Study of Computer Mediated Religious Communities. CSCW (2006).

65. Armfield, G., \& Holbert, R.: The Relationship between Religiosity \& Internet Use. Jrnl Media \& Religion, 2:3 (2003), 129-144.

66. Campbell, H.: A New Forum for Religion: Spiritual Pilgrimage Online. The Bible in Transmission (2001), Summer.

67. Campbell, H.: Challenges Created by Online Religious Networks. Jrnl Media \& Religion, 3: 2 (2004), 81-99.

68. Richardson, J.: Uses \& Gratifications of Agnostic Refuge: Case Study of a Skeptical Online Congregation. Jrnl Media \& Religion, 2:4, (2003) ,237-250.

69. Anon.: Russian Content Provider offers SMS Service to Wailing Wall in Jerusalem. Mosnews.com. 11/25 (2005).

70. Ananova.: Hi-tech Catholic confession banned. www.ananova.com. (2003).

71. Bruni, F.: Italians give thumbs up to wireless messages. NYTimes, $3 / 13$ (2003).

72. Charny, B.: Pope to Ping the faithful. clnet. 4/7 (2004).

73. Anon.: Archbishop requests SMS-free Good Friday.Catholic Tele. News, $3 / 22$ (2002).

74. Leland, J.:Tucked behind the home page, a call to worship.NY Times, 1/31 (2004).

75. Scott, D.: Matchmaker, Matchmaker, Find Me a Match: A cultural examination of a Virtual Community of Single Mormons. Jrl Media \& Religion, 1:4, (2002), 201-216.

76. Bezlova, A.: China: Battle with tradition spills into cyber-space - traditional funerals \& the internet. Relgioscope, 4/9 (2002). www_religioscope.com

77. Anon.: Chinese Grieve Loved Ones at Cyber-memorials. China Daily, 4/5(2003).

78. Anon.: China Mourns Fighter Pilot in Online Memorial Hall. Reuters, 4/21 (2001).

79. Anon.: Online Tomb-sweeping debuts in China. China Daily, 4/5 (2001).

80. Tan, D.: Qingming goes online. Radio Singapore International. Broadcast 10 (2002).

81. Anon.: Reader in Collection Plate. Associated Press, $2 / 18$ (2003).

82. Ralli, T.: Missed Church? Download It to your iPod. NY Times, 8/29 (2005).

83. Lin, Ed.: Spiritually Profitable Gaming. Forbes.com. 8/16 (2003).

84. Dee, J.: PlayStations of the Cross. NYTimes Magazine, 5/1 (2005).

85. Weiser, M.: The Computer for the $21^{\text {st }}$ Century. Scientific Am., 265: 3 (1991), 94-10.

86. Sengupta, U. \& Sherry, J.: Future Vision 2015. Tech@Intel Magazine, Sept (2004).

87. Weiser, M., Gold, R., Brown, J.S.: The Origins of ubiquitous computing research at PARC in the late 1980s. IBM Systems Journal, 38:4 (1999), 693-696.

88. Weiser, M. \& Brown, J.S.: The Coming Age of Calm Technology. In P Denning \& R Metcalfe (eds) Beyond Calculation: The Next Fifty Years of Computing, Spinger-Verlag, Inc. (1997). 